\title{
Temperature-Dependent Development and Survival Rates of Culex quinquefasciatus and Aedes aegypti (Diptera: Culicidae)
}

\author{
L. M. RUEDA, K. J. PATEL, R. C. AXTELL, AND R. E. STINNER \\ Department of Entomology, North Carolina State University, \\ Raleigh, North Carolina 27695
}

\begin{abstract}
J. Med. Entomol. 27(5): 892-898 (1990)
ABSTRACT Development, growth, and survival of Culex quinquefasciatus Say and Aedes aegypti (L.) were determined at six constant temperatures $\left(15,20,25,27,30,34^{\circ} \mathrm{C}\right)$. The Sharpe \& DeMichele four-parameter model with high-temperature inhibition described the temperature-dependent median developmental rates of both mosquito species. In both species, body size generally decreased as temperature increased. Head capsule widths in all instars in both species were significantly greater at 15 than at $30-34^{\circ} \mathrm{C}$. Except for the third instar of $\mathrm{Ae}$. aegypti, the larval body lengths in both species were significantly greater at 15 than at $34^{\circ} \mathrm{C}$. All instars and pupae of both species and the adults in Cx. quinquefasciatus were significantly heavier at 15 than at $27-34^{\circ} \mathrm{C}$. In $C x$. quinquefasciatus, survival from eclosion to adult emergence was highest in the range from 20 to $30^{\circ} \mathrm{C}(85-90 \%)$ and dropped drastically at $15(38 \%)$ and $34^{\circ} \mathrm{C}(42 \%)$. In Ae aegypti, survival to adult stage was high at $20(92 \%)$ and $27^{\circ} \mathrm{C}(90 \%)$ and lowest at $15^{\circ} \mathrm{C}(3 \%)$.
\end{abstract}

KEY WORDS Insecta, temperature-dependent development, Culex quinquefasciatus, Aedes aegypti

INFORMATION ON THE EFFECTS of temperature on the rates of development and survival of the various stages of mosquitoes are necessary in designing population and control strategy models (Wagner et al. 1975, Moon 1976, Haile \& Weidhaas 1977, Greever \& Georghiou 1979). Data on the effects of temperature on the development of Culex quinquefasciatus Say (Shelton 1973, Madder et al. 1983, Rayah \& Groun 1983, Kasule 1986, Service 1986) and Aedes aegypti (L.) (Bar-Zeev 1958, Kasule 1986, Southwood et al. 1972) have been reported. Unfortunately, the reported data were not collected in the appropriate form or published in sufficient detail to provide the distributions of values required for calculations in mathematical models of temperature-dependent development. Because of variation among individuals, populations must be sampled at several time intervals to document the distribution of development times. Closer sampling intervals are required at high temperatures than at low temperatures to obtain approximately equal numbers of data points within the range of the distribution.

In the study reported here, the effect of constant temperatures on the developmental rates, growth, and survival of the immature stages of Cx. quinquefasciatus and Ae. aegypti was determined under laboratory conditions, and the temperaturedependent model of Sharpe \& DeMichele (1977) was used to describe developmental rates. The distribution of development was described using the approach of Stinner et al. (1975).

\section{Materials and Methods}

Mosquito eggs used in these studies were obtained from laboratory colonies whose stock parents originated from Raleigh, N.C., within the previous 2 yr. Larvae hatching during the first hour after the eggs were placed on water at $27^{\circ} \mathrm{C}$ were used, and the developmental time was assumed to be at the midpoint of this $1-\mathrm{h}$ period. One larva was placed in each well $(7 \mathrm{ml})$ of a covered 12 well tissue culture plate (Cat. 25815; Corning Company, Corning, N.Y.) containing $3 \mathrm{ml}$ liver solution ( $0.26 \mathrm{mg}$ liver powder $/ \mathrm{ml}$ deionized water). Thirty plates were placed in each of five incubators (maintained at $15,20,25,30$, and $34^{\circ} \mathrm{C}$ ) and in a controlled-environment room $\left(27^{\circ} \mathrm{C}\right)$. Every second day, first and second instars were provided with 30 $\mu \mathrm{l}$ of liver solution per well, and third and fourth instars were given $50 \mu \mathrm{l}$. Water was added as needed to maintain the volume. Based on our observations of liver particles being present at all times in the cells, this feeding regimen provided excess food for the larvae at all temperatures. The incubators and the controlled room were illuminated continuously with fluorescent light. In a preliminary experiment, this procedure for rearing individual larvae in tissue culture plates under constant light was compared with our routine rearing in groups in pans under a 14:10 (L:D) photoperiod, and no differences in development times were observed.

Mosquito larvae were examined at intervals of 
Table 1. Mean, median, and predicted median number of days for development of $\boldsymbol{C}$. quinquefasciatus from egg hateh to adult emergence at six constant temperatures (15$34^{\circ} \mathrm{C}$ )

\begin{tabular}{|c|c|c|c|c|c|}
\hline \multirow[b]{2}{*}{ Life stage } & \multirow{2}{*}{$\begin{array}{l}\text { Temp, } \\
{ }^{\circ} \mathrm{C}\end{array}$} & \multirow[b]{2}{*}{$n^{a}$} & \multicolumn{3}{|c|}{ Days to complete each life stage } \\
\hline & & & $\begin{array}{c}\text { Observed } \\
\text { mean }( \pm \mathrm{SE})^{b}\end{array}$ & $\begin{array}{c}\text { Observed } \\
\text { median }\end{array}$ & $\begin{array}{c}\text { Predicted } \\
\text { median }\end{array}$ \\
\hline \multirow[t]{6}{*}{ First instar } & 15 & 348 & $5.79(0.09) \mathrm{a}$ & 5.84 & 4.47 \\
\hline & 20 & 352 & $1.85(0.02) \mathrm{b}$ & 1.87 & 2.17 \\
\hline & 25 & 350 & $1.39(0.04) c$ & 1.45 & 1.26 \\
\hline & 27 & 350 & $0.97(0.01) \mathrm{d}$ & 0.97 & 1.09 \\
\hline & 30 & 338 & $0.99(0.01) \mathrm{d}$ & 0.99 & 0.94 \\
\hline & 34 & 360 & $0.84(0.01) \mathrm{d}$ & 0.89 & 0.90 \\
\hline \multirow[t]{6}{*}{ Second instar } & 15 & 279 & $4.56(0.13) \mathrm{a}$ & 4.47 & 3.97 \\
\hline & 20 & 330 & $1.64(0.02) b$ & 1.64 & 1.86 \\
\hline & 25 & 317 & $1.44(0.02) b$ & 1.42 & 1.04 \\
\hline & 27 & 328 & $0.71(0.01) \mathrm{c}$ & 0.69 & 0.89 \\
\hline & 30 & 314 & $0.89(0.01) c$ & 0.88 & 0.77 \\
\hline & 34 & 354 & $0.79(0.01) c$ & 0.73 & 0.74 \\
\hline \multirow[t]{6}{*}{ Third instar } & 15 & 230 & $6.43(0.21) \mathrm{a}$ & 5.22 & 3.84 \\
\hline & 20 & 274 & $1.98(0.08) b$ & 1.82 & 2.17 \\
\hline & 25 & 275 & $1.65(0.04) \mathrm{b}$ & 1.69 & 1.39 \\
\hline & 27 & 246 & $1.03(0.03) \mathrm{c}$ & 1.02 & 1.22 \\
\hline & 30 & 243 & $1.24(0.05) \mathrm{c}$ & 1.19 & 1.07 \\
\hline & 34 & 259 & $1.10(0.04) \mathrm{c}$ & 1.03 & 1.05 \\
\hline \multirow{6}{*}{ Fourth instar } & 15 & 161 & $8.57(0.19) \mathrm{a}$ & 8.14 & 6.94 \\
\hline & 20 & 207 & $4.06(0.06) b$ & 4.07 & 4.68 \\
\hline & 25 & 228 & $3.47(0.08) \mathrm{c}$ & 3.44 & 3.20 \\
\hline & 27 & 200 & $2.67(0.05) \mathrm{d}$ & 2.68 & 2.76 \\
\hline & 30 & 178 & $2.29(0.03) \mathrm{d}$ & 2.28 & 2.26 \\
\hline & 34 & 182 & $2.45(0.08) \mathrm{d}$ & 2.36 & 2.37 \\
\hline \multirow[t]{6}{*}{ Pupa } & 15 & 52 & $6.03(0.21) \mathrm{a}$ & 5.98 & 4.71 \\
\hline & 20 & 164 & $2.54(0.04) \mathrm{b}$ & 2.50 & 2.98 \\
\hline & 25 & 178 & $2.33(0.03) b$ & 2.36 & 2.03 \\
\hline & 27 & 166 & $1.65(0.04) \mathrm{c}$ & 1.64 & 1.82 \\
\hline & 30 & 145 & $1.79(0.05) c$ & 1.71 & 1.65 \\
\hline & 34 & 73 & $1.84(0.07) \mathrm{c}$ & 1.72 & 1.72 \\
\hline \multirow[t]{6}{*}{ Total ${ }^{c}$} & 15 & 52 & $31.35(0.46) \mathrm{a}$ & 31.10 & 27.19 \\
\hline & 20 & 164 & $12.07(0.14) \mathrm{b}$ & 12.09 & 13.82 \\
\hline & 25 & 178 & $10.52(0.12) \mathrm{c}$ & 10.50 & 8.72 \\
\hline & 27 & 166 & $7.07(0.05) \mathrm{d}$ & 7.02 & 7.79 \\
\hline & 30 & 145 & $7.21(0.06) \mathrm{d}$ & 7.07 & 7.07 \\
\hline & 34 & 73 & $7.08(0.06) \mathrm{d}$ & 6.97 & 6.91 \\
\hline
\end{tabular}

${ }^{a}$ Total completing each life stage.

$b$ Means followed by the same letter within each life stage are not significantly different $(P>0.05$; Tukey's test [SAS Institute 1982]).

${ }^{c}$ Egg hatch to adult emergence.

4-8 $\mathrm{h}$ for molting (determined by the presence of exuviae). Molting was considered to have occurred at the midpoint of the time interval preceding the time when the molt was detected.

Larval wet weights, body lengths, head capsule widths of the exuviae, and the wet weights of pupae and adults were determined by destructive sampling. Twenty specimens of each instar (four specimens in each of five replicates) were used for each species and each temperature for the measurements of larvae, larval exuviae, and pupae. Larval length was measured from the most anterior part of the head to the posterior margin of the 10th abdominal segment under a binocular microscope. The larvae and pupae were sponged free of water with a piece of filter paper before they were weighed. The head capsules of the larval exuviae
Table 2. Mean, median, and predicted median number of days for development of Ae. aegypti from egg hatch to adult emergence at six constant temperatures $\left(15-34^{\circ} \mathrm{C}\right)$

\begin{tabular}{|c|c|c|c|c|c|}
\hline \multirow[b]{2}{*}{ Life stage } & \multirow{2}{*}{$\begin{array}{l}\text { Temp, } \\
{ }^{\circ} \mathrm{C}\end{array}$} & \multirow[b]{2}{*}{$n^{a}$} & \multicolumn{3}{|c|}{ Days to complete each life stage } \\
\hline & & & $\begin{array}{c}\text { Observed } \\
\text { mean }( \pm \mathrm{SE})^{b}\end{array}$ & $\begin{array}{c}\text { Observed } \\
\text { median }\end{array}$ & $\begin{array}{c}\text { Predicted } \\
\text { median }\end{array}$ \\
\hline First instar & $\begin{array}{l}15 \\
20 \\
25 \\
27 \\
30 \\
34\end{array}$ & $\begin{array}{l}318 \\
337 \\
284 \\
344 \\
284 \\
254\end{array}$ & $\begin{array}{l}7.67(0.14) \mathrm{a} \\
2.67(0.11) \mathrm{b} \\
2.74(0.12) \mathrm{b} \\
0.96(0.03) \mathrm{c} \\
1.18(1.07) \mathrm{cd} \\
1.42(0.03) \mathrm{d}\end{array}$ & $\begin{array}{l}7.68 \\
2.55 \\
2.69 \\
0.98 \\
1.16 \\
1.40\end{array}$ & $\begin{array}{l}7.87 \\
3.39 \\
1.59 \\
1.26 \\
1.07 \\
1.43\end{array}$ \\
\hline Second instar & $\begin{array}{l}15 \\
20 \\
25 \\
27 \\
30 \\
34\end{array}$ & $\begin{array}{l}190 \\
301 \\
242 \\
291 \\
240 \\
211\end{array}$ & $\begin{array}{l}8.88(0.40) \mathrm{a} \\
1.43(0.11) \mathrm{b} \\
1.35(0.05) \mathrm{b} \\
0.77(0.03) \mathrm{b} \\
0.89(0.05) \mathrm{b} \\
1.31(0.04) \mathrm{b}\end{array}$ & $\begin{array}{l}8.19 \\
1.45 \\
1.27 \\
0.71 \\
0.86 \\
1.31\end{array}$ & $\begin{array}{l}7.02 \\
2.37 \\
0.96 \\
0.78 \\
0.82 \\
1.51\end{array}$ \\
\hline Third instar & $\begin{array}{l}15 \\
20 \\
25 \\
27 \\
30 \\
34\end{array}$ & $\begin{array}{r}93 \\
262 \\
172 \\
251 \\
201 \\
167\end{array}$ & $\begin{array}{r}14.97(0.83) \mathrm{a} \\
1.62(0.05) \mathrm{b} \\
1.37(0.06) \mathrm{b} \\
0.96(0.03) \mathrm{b} \\
0.98(0.03) \mathrm{b} \\
0.84(0.04) \mathrm{b}\end{array}$ & $\begin{array}{r}13.92 \\
1.61 \\
1.48 \\
0.99 \\
0.93 \\
0.85\end{array}$ & $\begin{array}{r}10.99 \\
3.32 \\
1.27 \\
0.99 \\
0.84 \\
0.95\end{array}$ \\
\hline Fourth instar & $\begin{array}{l}15 \\
20 \\
25 \\
27 \\
30 \\
34\end{array}$ & $\begin{array}{r}30 \\
221 \\
139 \\
207 \\
161 \\
130\end{array}$ & $\begin{array}{c}15.31(1.22) \mathrm{a} \\
3.59(0.07) \mathrm{b} \\
3.15(0.06) \mathrm{bc} \\
1.78(0.03) \mathrm{d} \\
1.94(0.04) \mathrm{cd} \\
1.49(0.05) \mathrm{d}\end{array}$ & $\begin{array}{r}16.03 \\
3.45 \\
3.26 \\
1.78 \\
1.91 \\
1.48\end{array}$ & $\begin{array}{r}14.06 \\
5.37 \\
2.51 \\
2.03 \\
1.67 \\
1.58\end{array}$ \\
\hline Pupa & $\begin{array}{l}15 \\
20 \\
25 \\
27 \\
30 \\
34\end{array}$ & $\begin{array}{r}4 \\
162 \\
75 \\
142 \\
127 \\
97\end{array}$ & $\begin{array}{l}8.49(1.13) \mathrm{a} \\
3.11(0.07) \mathrm{b} \\
3.03(0.04) \mathrm{b} \\
1.79(0.03) \mathrm{c} \\
1.82(0.04) \mathrm{c} \\
1.09(0.03) \mathrm{d}\end{array}$ & $\begin{array}{l}8.46 \\
3.04 \\
2.98 \\
1.81 \\
1.79 \\
1.05\end{array}$ & $\begin{array}{l}6.90 \\
4.10 \\
2.50 \\
2.06 \\
1.56 \\
1.08\end{array}$ \\
\hline Total ${ }^{c}$ & $\begin{array}{l}15 \\
20 \\
25 \\
27 \\
30 \\
34\end{array}$ & $\begin{array}{r}4 \\
162 \\
75 \\
142 \\
127 \\
97\end{array}$ & $\begin{array}{r}55.33(3.55) \mathrm{a} \\
12.43(0.19) \mathrm{b} \\
11.72(0.11) \mathrm{b} \\
6.36(0.04) \mathrm{c} \\
6.86(0.04) \mathrm{c} \\
6.15(0.05) \mathrm{c}\end{array}$ & \begin{tabular}{r|}
58.31 \\
12.49 \\
11.57 \\
6.49 \\
6.89 \\
6.29
\end{tabular} & $\begin{array}{r}47.85 \\
18.61 \\
8.86 \\
7.30 \\
6.32 \\
6.67\end{array}$ \\
\hline
\end{tabular}

${ }^{a}$ Total completing each life stage.

${ }^{b}$ Means followed by the same letter within each life stage are not significantly different $(P>0.05$; Tukey's test [SAS Institute 1982]).

${ }^{c}$ Egg hatch to adult emergence.

were immersed in $70 \%$ ethyl alcohol in a glass depression slide and measured at their maximum width under a binocular microscope. Thirty adults (15 males and 15 females at each temperature) were aspirated from the wells, anesthetized with carbon dioxide, and weighed individually within $1 \mathrm{~h}$ after emergence. Morphometric data were tested by analysis of variance using a general linear model (GLM) procedure (SAS Institute 1982).

Survival was based on the number of the larvae at the start of each experiment and was calculated for each instar and stage. After arcsine transformation of the data, differences in survival among temperatures were tested for significance using $\mathrm{Tu}$ key's test $(P=0.05)$.

For each mosquito species, the four-parameter version of the Sharpe \& DeMichele (1977) nonlin- 
Table 3. Parameter estimates for the Sharpe \& DeMichele model (Equation 1) and $R^{2}$ of the model fit to observed median development rates of $C x$. quinquefasciatus and Ae. aegypti

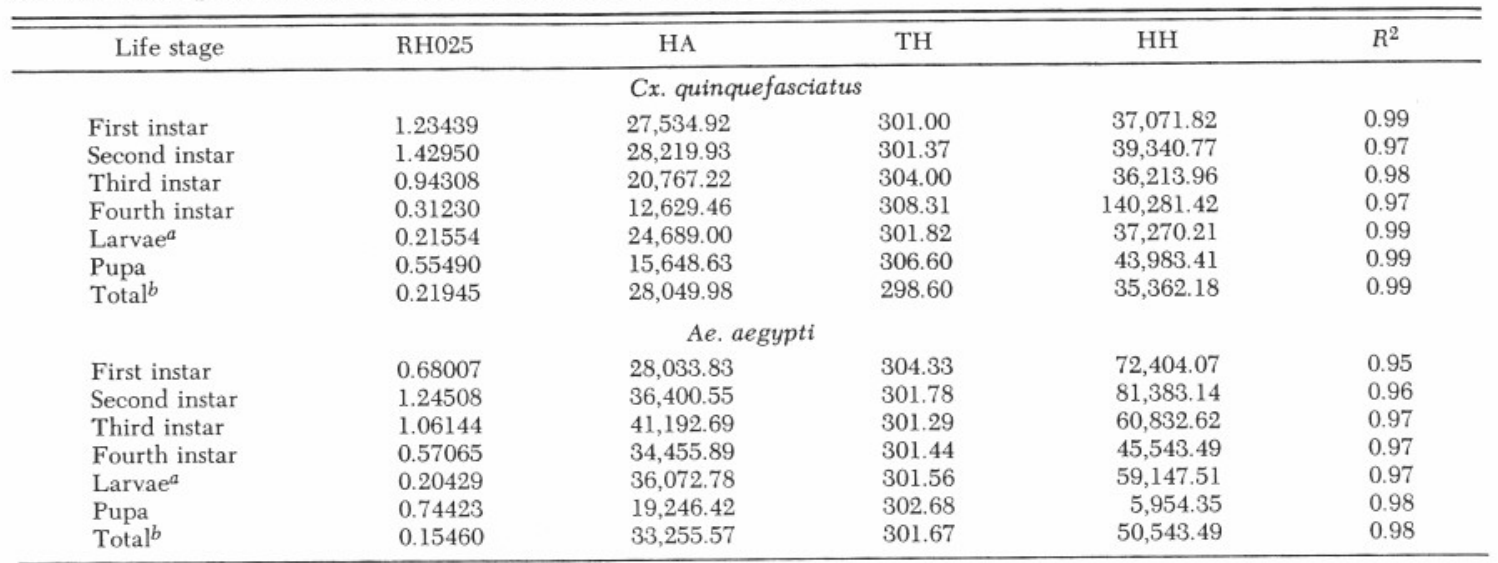

${ }^{a}$ First through fourth instars.

${ }^{b}$ Egg hatch to adult emergence.

ear model of temperature-dependent poikilotherm processes was used to describe the effect of constant temperature on median development rate (reciprocal of median number of days to complete development). The Sharpe \& DeMichele model with high temperature inhibition is shown in Equation 1:

$$
\begin{aligned}
& r(K)= \\
& \text { RH025 } \frac{K}{298.15} \cdot \exp \left[\frac{\mathrm{HA}}{1.987}\left(\frac{1}{298.15}-\frac{1}{K}\right)\right] \\
& 1+\exp \left[\frac{\mathrm{HH}}{1.987}\left(\frac{1}{\mathrm{TH}}-\frac{1}{K}\right)\right]
\end{aligned}
$$

where $r(K)$ is the median development rate $\left(\right.$ days $\left.^{-1}\right)$ at temperature $K\left({ }^{\circ} \mathrm{Kelvin}={ }^{\circ} \mathrm{C}+273.15\right)$. $\mathrm{RH} 025$, $\mathrm{HA}, \mathrm{TH}$, and $\mathrm{HH}$ are parameters estimated by a nonlinear regression routine outlined by Wagner et al. (1984) for use in the NLIN procedure (SAS Institute 1982). Once the parameters are determined, the equation can be used to calculate development rates at any temperature and used in a population simulation model with variable temperature input. Schoolfield et al. (1981) discuss the biological significance of these parameters.

Model parameters were estimated for each life stage (i.e., first, second, third, fourth instars, pupa), combined development time of first to fourth larval stadia, and total development time from egg hatch to adult emergence. In each case, the goodness of fit was tested using a linear regression of the predicted versus observed values to calculate $R^{2}$ and was tested for a slope of 1 and intercept of 0 (REG procedure) (SAS Institute 1982).

Development rates of insects exposed to constant temperature cannot be assumed to be normally distributed. Therefore, the approach of Stinner et al. (1975) was used to construct a model for vari- ation in the total time from egg hatch to adult emergence. For each temperature, median physiological ages at first and last emergence were calculated. These physiological ages were averaged over all temperatures, resulting in a median of 0.89 at first emergence and 1.17 at $100 \%$ emergence. By definition, $50 \%$ emergence occurs at a median physiological age of 1.0. The cumulative proportion of the mosquito population completing development $(y)$ at median physiological age $(p)$ is described by Equation 2:

$$
y=(1-z)^{2.0126 z^{2}}
$$

Here, $z=(1.17-p) /(1.17-0.89)$. Thus, the distribution of development is expressed as a function of the median physiological age, and this relationship remains constant over all temperatures. The median physiological age at any time (days) at any temperature is calculated by multiplying the estimated median rate of development at that temperature by that chronological time (days).

\section{Results and Discussion}

The observed development times (mean and median) and the predicted medians calculated from the Sharpe \& DeMichele (1977) model (Equation 1 and parameters in Table 3) for Cx. quinquefasciatus and Ae. aegypti are given in Tables 1 and 2. For Cx. quinquefasciatus, there was a significant decrease in the number of days required for total development (from egg hatch to adult emergence) between temperatures of $15-27^{\circ} \mathrm{C}$ but no further significant decrease at 30 and $34^{\circ} \mathrm{C}$. A similar trend of significant decrease in development times was observed for all larval stadia and the pupal stage. For Ae. aegypti, a significant decrease in number of days required for development in second and third stadia at $15-20^{\circ} \mathrm{C}$ was observed. No further 


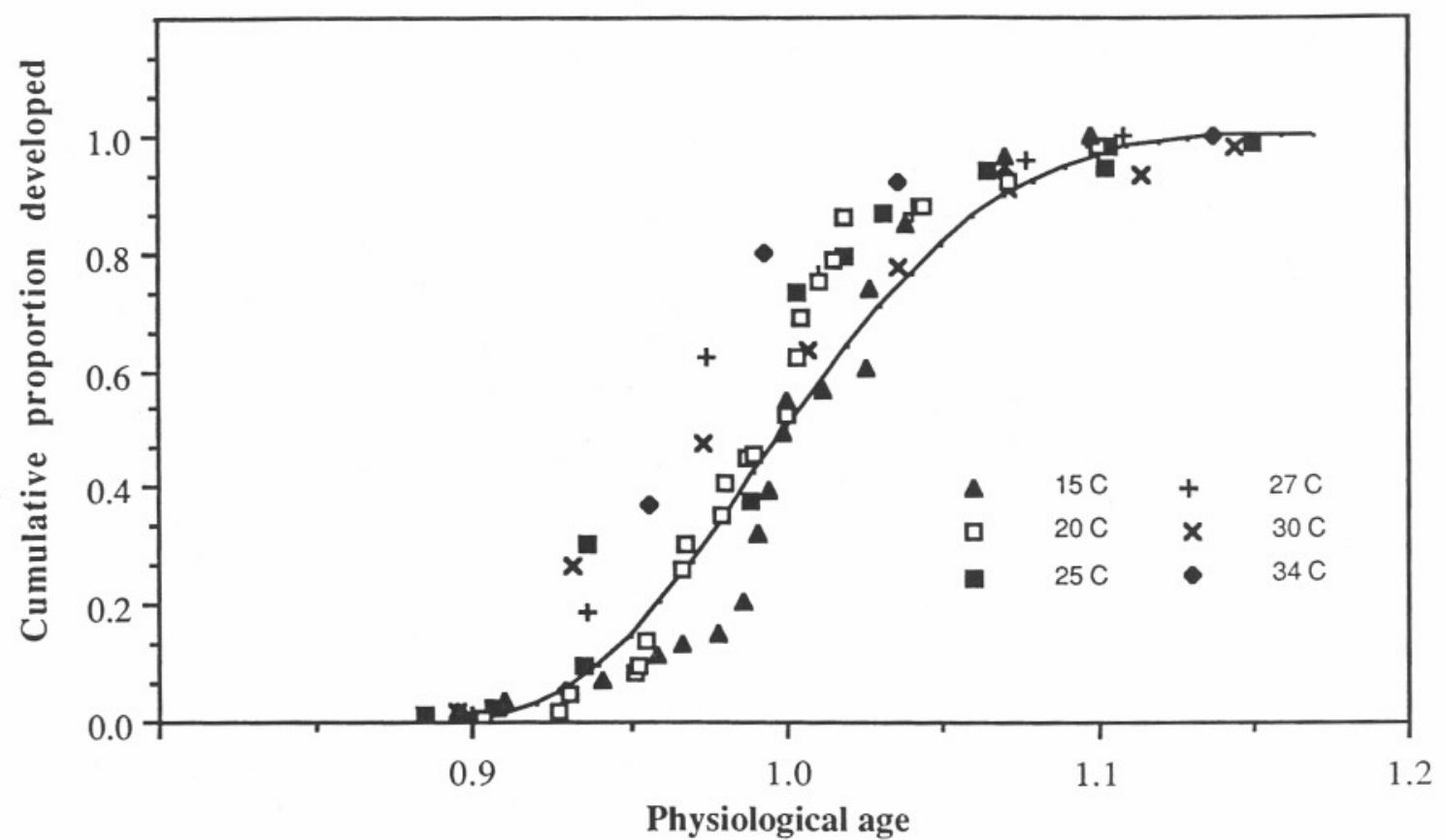

Fig. 1. Cumulative proportion of Cx. quinquefasciatus population completing development from egg hatch to adult emergence as a function of median physiological age. Line represents predicted distribution; points represent observed distribution at six temperatures.

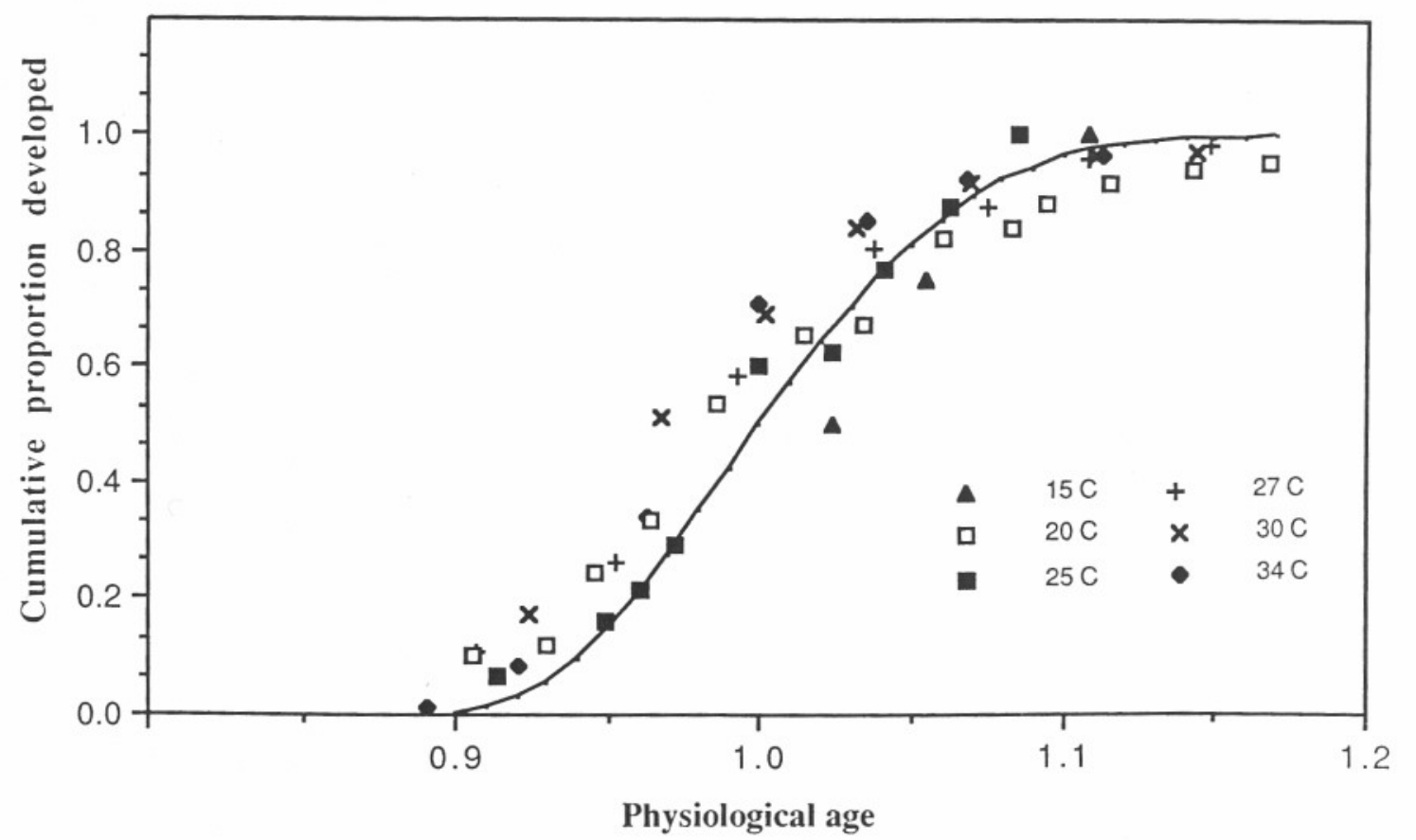

Fig. 2. Cumulative proportion of Ae. aegypti population completing development from egg hatch to adult emergence as a function of median physiological age. Line represents predicted distribution; points represent observed distribution at six temperatures. 
Table 4. Mean widths (mm) of larval head capsule, larval body lengths ( $\mathrm{mm}$ ), and the larval, pupal, and adult body weights (mg) of $\boldsymbol{C} x$. quinquefasciatus reared at six constant temperatures

\begin{tabular}{|c|c|c|c|c|c|c|}
\hline \multirow{2}{*}{$\begin{array}{c}\text { Life stage } \\
\text { and parameter }\end{array}$} & \multicolumn{6}{|c|}{ Temp, ${ }^{\circ} \mathrm{C}$} \\
\hline & 15 & 20 & 25 & 27 & 30 & 34 \\
\hline \multicolumn{7}{|l|}{ First instar } \\
\hline Head width & $0.33 \mathrm{a}$ & $0.32 \mathrm{ab}$ & $0.31 b$ & $0.31 b$ & $0.31 b$ & $0.31 b$ \\
\hline \multicolumn{7}{|l|}{ Second instar } \\
\hline Head width & $0.51 \mathrm{a}$ & $0.51 \mathrm{a}$ & $0.51 \mathrm{a}$ & $0.51 \mathrm{a}$ & $0.49 \mathrm{~b}$ & $0.50 \mathrm{~b}$ \\
\hline Body length & $2.40 \mathrm{a}$ & $2.29 \mathrm{~b}$ & $2.27 \mathrm{~b}$ & $2.28 \mathrm{~b}$ & $2.25 b$ & $2.19 \mathrm{c}$ \\
\hline Body weight & $0.65 a$ & $0.60 \mathrm{ab}$ & $0.59 \mathrm{ab}$ & $0.54 \mathrm{~b}$ & $0.54 \mathrm{~b}$ & $0.43 \mathrm{c}$ \\
\hline \multicolumn{7}{|l|}{ Third instar } \\
\hline Head width & $0.82 \mathrm{a}$ & $0.82 \mathrm{a}$ & $0.78 \mathrm{~b}$ & $0.77 \mathrm{bc}$ & $0.78 \mathrm{~b}$ & $0.76 \mathrm{c}$ \\
\hline Body length & $3.79 \mathrm{a}$ & 3.73ab & $3.68 \mathrm{bc}$ & $3.72 \mathrm{~b}$ & $3.65 c$ & $3.63 \mathrm{c}$ \\
\hline Body weight & $1.23 \mathrm{a}$ & $1.02 \mathrm{ab}$ & $0.81 \mathrm{~b}$ & $0.71 b$ & $0.70 \mathrm{~b}$ & $0.69 \mathrm{~b}$ \\
\hline \multicolumn{7}{|l|}{ Fourth instar } \\
\hline Head width & $1.25 \mathrm{a}$ & $1.21 \mathrm{ab}$ & $1.18 \mathrm{~b}$ & $1.19 \mathrm{~b}$ & $1.17 \mathrm{~b}$ & $1.11 \mathrm{c}$ \\
\hline Body length & $5.71 \mathrm{a}$ & $5.63 \mathrm{ab}$ & $5.59 \mathrm{ab}$ & $5.50 \mathrm{~b}$ & $5.33 \mathrm{c}$ & $5.31 \mathrm{c}$ \\
\hline Body weight & $3.52 \mathrm{a}$ & $2.89 \mathrm{~b}$ & $2.59 \mathrm{~b}$ & $2.74 \mathrm{~b}$ & $2.55 \mathrm{~b}$ & $2.45 \mathrm{c}$ \\
\hline \multicolumn{7}{|l|}{ Pupa } \\
\hline Body weight & $5.77 \mathrm{a}$ & $4.01 \mathrm{bc}$ & $4.42 \mathrm{~b}$ & $3.68 \mathrm{bc}$ & $3.46 \mathrm{c}$ & $3.59 \mathrm{c}$ \\
\hline \multicolumn{7}{|l|}{ Female adult } \\
\hline Body weight & $2.81 \mathrm{a}$ & $1.64 \mathrm{c}$ & $1.95 \mathrm{~b}$ & $2.17 \mathrm{~b}$ & $1.95 \mathrm{~b}$ & $1.95 \mathrm{~b}$ \\
\hline \multicolumn{7}{|l|}{ Male adult } \\
\hline Body weight & $2.10 \mathrm{a}$ & $1.25 \mathrm{~d}$ & $1.74 \mathrm{~b}$ & $1.47 \mathrm{c}$ & $1.35 \mathrm{~cd}$ & $1.73 \mathrm{~b}$ \\
\hline \multicolumn{7}{|l|}{ Combined adults } \\
\hline Body weight & $2.45 \mathrm{a}$ & $1.45 \mathrm{c}$ & $1.85 \mathrm{~b}$ & $1.82 \mathrm{~b}$ & $1.65 \mathrm{bc}$ & $1.84 \mathrm{~b}$ \\
\hline
\end{tabular}

Means followed by the same letter within rows are not significantly different $(P>0.05$; Tukey's test [SAS Institute 1982])

significant decrease, however, was recorded at 25$34^{\circ} \mathrm{C}$. For the total developmental period and for other larval and pupal stadia, Ae. aegypti exhibited significant decreases similar to those for $C x$. quinquefasciatus.

The percentages (and range) of total development time, over the entire range of temperatures, spent in each immature stage by $C x$. quinquefasciatus were: $14 \%$ (11.9-18.4) for first stadium, $13 \%$ (10.1-14.5) for second stadium, 17\% (14.7-20.4) for third stadium, 33\% (27.3-37.9) for fourth stadium, and $23 \%(19.2-26.2)$ for the pupal stage. For Ae. aegypti, the percentages were: $19 \%$ (13.9-23.1) for first stadium, $14 \%(11.3-21.3)$ for second stadium, $17 \%$ (13.0-27.0) for the third stadium, $27 \%$ (24.2-28.5) for fourth stadium, and $23 \%(15.3-28.5)$ for the pupal stage.

The four-parameter Sharpe \& DeMichele model (Equation 1) incorporating high-temperature inhibition described the temperature-dependent median development rates of both mosquito species very well (Table 3 ). The $R^{2}$ values ranged from 0.97 to 0.99 and from 0.95 to 0.98 for Cx. quinquefasciatus and Ae. aegypti, respectively. Cx. yuinquefasciatus and Ae. aegypti reached maximum median development rates $\left(\right.$ days $\left.^{-1}\right)$ of 0.143 and 0.159 , respectively, at $34^{\circ} \mathrm{C}$.

The predicted (using the method of Stinner et al. 1975) and estimated cumulative proportion of individual mosquitoes completing development as a function of estimated physiological age are pre- sented in Fig. 1 and 2. Inaccuracies in the estimation of developmental rates are expressed by any divergence of the observed data from the predicted curve. For example, in both species, the predicted total developmental rates were low at $15^{\circ} \mathrm{C}$ and slightly high at $25^{\circ} \mathrm{C}$. In Ae. aegypti, only a few individuals were able to complete development at $15^{\circ} \mathrm{C}$.

Published reports on development times for $C x$. quinquefasciatus and Ae. aegypti do not present as detailed data for each larval instar and pupae as does our study; consequently, comparisons other than overall development times (egg to adult emergence) are difficult to make. In our study, developmental times for $C x$. quinquefasciatus were longer than those reported by Shelton (1973) and Madder et al. (1983). For example, comparing our data for 15 and $20^{\circ} \mathrm{C}$ with those of Shelton (1973) for the period from first instar to adult emergence, our mean developmental times were about 19.8 and $4.1 \mathrm{~d}$ longer, respectively. Our mean developmental times for the same period and temperatures were about 4.3 and $0.5 \mathrm{~d}$, respectively, longer than those observed by Madder et al. (1983). In Ae. aegypti, our mean development times at $20^{\circ} \mathrm{C}$ were about $5 \mathrm{~d}$ shorter than that reported by BarZeev (1958). At 30 and $34^{\circ} \mathrm{C}$, however, our development times were similar to those of Bar-Zeev (1958). These differences could be caused by single versus group rearing or by different strains of mosquitoes used in the studies. Variations in life table 
Table 5. Mean widths ( $\mathrm{mm}$ ) of larval head capsule, larval body lengths ( $\mathrm{mm}$ ), and the larval, pupal, and adult body weights (mg) of Ae. aegypti reared at six constant temperatures

\begin{tabular}{|c|c|c|c|c|c|c|}
\hline \multirow{2}{*}{$\begin{array}{c}\text { Life stage } \\
\text { and parameter }\end{array}$} & \multicolumn{6}{|c|}{ Temp, ${ }^{\circ} \mathrm{C}$} \\
\hline & 15 & 20 & 25 & 27 & 30 & 34 \\
\hline \multicolumn{7}{|l|}{ First instar } \\
\hline Head width & $0.28 \mathrm{a}$ & $0.26 \mathrm{~b}$ & $0.26 \mathrm{~b}$ & $0.26 \mathrm{~b}$ & $0.25 \mathrm{~b}$ & $0.23 c$ \\
\hline \multicolumn{7}{|l|}{ Sècond instar } \\
\hline $\begin{array}{l}\text { Head width } \\
\text { Body length } \\
\text { Body weight }\end{array}$ & $\begin{array}{l}0.47 \mathrm{a} \\
3.19 \mathrm{a} \\
0.74 \mathrm{a}\end{array}$ & $\begin{array}{l}0.46 \mathrm{ab} \\
3.19 \mathrm{a} \\
0.59 \mathrm{~b}\end{array}$ & $\begin{array}{l}0.46 \mathrm{ab} \\
3.06 \mathrm{~b} \\
0.56 \mathrm{bc}\end{array}$ & $\begin{array}{l}0.46 \mathrm{ab} \\
2.92 \mathrm{c} \\
0.49 \mathrm{bcd}\end{array}$ & $\begin{array}{l}0.45 \mathrm{~b} \\
2.79 \mathrm{~d} \\
0.46 \mathrm{~cd}\end{array}$ & $\begin{array}{l}0.44 \mathrm{~b} \\
2.80 \mathrm{~d} \\
0.42 \mathrm{~d}\end{array}$ \\
\hline \multicolumn{7}{|l|}{ Third instar } \\
\hline $\begin{array}{l}\text { Head width } \\
\text { Body length } \\
\text { Body weight }\end{array}$ & $\begin{array}{l}0.75 \mathrm{a} \\
4.43 \mathrm{a} \\
1.60 \mathrm{a}\end{array}$ & $\begin{array}{l}0.74 \mathrm{ab} \\
4.33 \mathrm{a} \\
1.64 \mathrm{a}\end{array}$ & $\begin{array}{l}0.71 \mathrm{bc} \\
4.34 \mathrm{a} \\
1.36 \mathrm{~b}\end{array}$ & $\begin{array}{l}0.72 \mathrm{~b} \\
4.39 \mathrm{a} \\
1.34 \mathrm{~b}\end{array}$ & $\begin{array}{l}0.69 \mathrm{c} \\
4.36 \mathrm{a} \\
1.25 \mathrm{~b}\end{array}$ & $\begin{array}{l}0.67 \mathrm{~d} \\
4.30 \mathrm{a} \\
1.09 \mathrm{~b}\end{array}$ \\
\hline \multicolumn{7}{|l|}{ Fourth instar } \\
\hline $\begin{array}{l}\text { Head width } \\
\text { Body length } \\
\text { Body weight }\end{array}$ & $\begin{array}{l}0.98 \mathrm{a} \\
6.57 \mathrm{a} \\
4.29 \mathrm{a}\end{array}$ & $\begin{array}{l}0.99 \mathrm{a} \\
6.47 \mathrm{a} \\
4.21 \mathrm{a}\end{array}$ & $\begin{array}{l}0.97 \mathrm{a} \\
6.41 \mathrm{a} \\
4.01 \mathrm{ab}\end{array}$ & $\begin{array}{l}0.93 \mathrm{~b} \\
6.44 \mathrm{a} \\
3.72 \mathrm{ab}\end{array}$ & $\begin{array}{l}0.93 \mathrm{~b} \\
6.39 \mathrm{ab} \\
3.04 \mathrm{bc}\end{array}$ & $\begin{array}{l}0.92 b \\
6.12 b \\
2.35 c\end{array}$ \\
\hline \multicolumn{7}{|l|}{ Pupa } \\
\hline Body weight & $5.98 \mathrm{a}$ & $5.76 \mathrm{a}$ & $4.24 \mathrm{~b}$ & $4.03 \mathrm{bc}$ & $3.95 \mathrm{bc}$ & $3.20 \mathrm{c}$ \\
\hline \multicolumn{7}{|l|}{ Female adult } \\
\hline Body weight & - & $2.07 \mathrm{a}$ & $1.59 \mathrm{~b}$ & $1.19 \mathrm{c}$ & $2.07 \mathrm{a}$ & $1.65 \mathrm{~b}$ \\
\hline \multicolumn{7}{|l|}{ Male adult } \\
\hline Body weight & - & $1.29 \mathrm{a}$ & $1.11 \mathrm{~b}$ & $0.76 \mathrm{~d}$ & $1.20 \mathrm{a}$ & $0.93 \mathrm{c}$ \\
\hline \multicolumn{7}{|l|}{ Combined adults } \\
\hline Body weight & 一 & $1.68 \mathrm{a}$ & $1.35 \mathrm{~b}$ & $0.97 \mathrm{c}$ & $1.64 \mathrm{a}$ & $1.29 b$ \\
\hline
\end{tabular}

Means followed by the same letter within rows are not significantly different $(P>0.05$; Tukey's test [SAS Institute 1982]).

parameters among different strains of Ae. aegypti and $C x$. quinquefasciatus have been reported by Crovello \& Hacker (1972) and Walter \& Hacker (1974), respectively, but their conclusions were based on data collected at only one temperature. Given the parameter values in Table 3, the Sharpe \& DeMichele model may describe adequately the temperature-dependent development of other strains of these species and that could be verified by comparison with data on total development time collected at two or three temperatures. If necessary, the parameters could be changed to fit the data obtained with other strains more adequately.

Temperature affected the head capsule widths, body lengths, and weights in Cx. quinquefasciatus and Ae aegypti (Tables 4 and 5). For both species, body size generally decreased as temperature increased. The head capsules of all instars in both species were significantly wider at 15 than at 30 and $34^{\circ} \mathrm{C}$. Except for the third instar of Ae. aegypti, the larvae in both species were significantly longer at 15 than at $34^{\circ} \mathrm{C}$. The body weights of all instars and pupae of both species, and the adult males and females of Cx. quinquefasciatus, were significantly greater at 15 than at $30-34^{\circ} \mathrm{C}$. The inverse relationship between temperature and body size could possibly be the result of more rapid development at higher temperatures (Laudien 1973). The growth rate may increase with temperature, but the decrease in time available for growth has a greater effect on the size. Thus, the resulting insect is smaller (McHugh \& Olson 1982).

Both species developed to the adult stage at all constant temperatures tested (Table 6). In Cx. quinquefasciatus, survival to adult stage was significantly lower at 15 and $34^{\circ} \mathrm{C}$ than at $20-30^{\circ} \mathrm{C}$. On the other hand, Ae. aegypti had significantly lower survival to adult stage at 15 than at $20-34^{\circ} \mathrm{C}$, and its highest survival rate was recorded at 20 and $27^{\circ} \mathrm{C}$. The proportion of the total mortality, averaged over all temperatures, which occurred during each immature stage differed for Cx. quinquefasciatus and Ae. aegypti, with about 15 and $78 \%$ for first instar, 13 and $9 \%$ for second instar, 6 and $7 \%$

Table 6. Effect of constant temperatures on Cx. quinquefasciatus and Ae. aegypti survival from egg hatch to adult stage

\begin{tabular}{ccc}
\hline \hline \multirow{2}{*}{$\begin{array}{c}\text { Temp, } \\
{ }^{\circ} \mathrm{C}\end{array}$} & \multicolumn{2}{c}{ Mean $( \pm \mathrm{SE})$ survival, \% } \\
\cline { 2 - 3 } & Cx. quinquefasciatus & Ae. aegypti \\
\hline 15 & $38.15(2.89) \mathrm{a}$ & $3.11(1.33) \mathrm{a}$ \\
20 & $85.25(2.62) \mathrm{b}$ & $91.80(3.05) \mathrm{c}$ \\
25 & $90.30(1.41) \mathrm{b}$ & $62.58(2.49) \mathrm{b}$ \\
27 & $84.87(2.72) \mathrm{b}$ & $89.76(3.75) \mathrm{c}$ \\
30 & $83.12(1.63) \mathrm{b}$ & $66.34(2.74) \mathrm{b}$ \\
34 & $42.07(2.02) \mathrm{a}$ & $59.14(3.08) \mathrm{b}$ \\
\hline
\end{tabular}

Data subjected to arcsine transformation for analysis. Mean percentages in the same column followed by the same letter are not significantly different $(P>0.05$; Tukey's test [SAS Institute 1982]). 
for third instar, 21 and $4 \%$ for fourth instar, and 42 and $2 \%$ for pupal stage, respectively. For $C x$. quinquefasciatus, high survival at midrange temperatures $\left(20-30^{\circ} \mathrm{C}\right)$ was evident, with survival drastically decreasing above and below that range. A similar trend was observed by Shelton (1973) for this species. For Ae. aegypti, the lowest immature survival $(3 \%)$ was observed at $15^{\circ} \mathrm{C}$, whereas the highest survivals were at $20(92 \%)$ and $27^{\circ} \mathrm{C}(90 \%)$. Bar-Zeev (1958) reported highest larval and pupal survival of Ae. aegypti at $20^{\circ} \mathrm{C}$, but none survived at $14^{\circ} \mathrm{C}$. The techniques used in our study apparently inflicted minimal mortality because survival to the adult stage at 20 and $30^{\circ} \mathrm{C}$ in $\mathrm{Cx}$. quinquefasciatus and Ae. aegypti was greater than reported by Madder et al. (1983) and Bar-Zeev (1958), respectively.

Our data on temperature-dependent development, and our demonstration of the fit of the Sharpe \& DeMichele model with appropriate parameters, provide a major component required for the development of simulation models for the population dynamics of these mosquito species. Obviously, the effects of other factors (e.g., food quality, water quality, light regimen, adult survival, and oviposition) in addition to temperature also must be included in such simulation models.

\section{Acknowledgment}

This is paper 12396 of the Journal Series of the North Carolina Agricultural Research Service, Raleigh. This research was supported in part by National Institute of Health grant AI 20886 and by financial support from the United Nations Development Program/World Bank/ World Health Organization Special Programme for Research and Training in Tropical Diseases.

\section{References Cited}

Bar-Zeev, M. 1958. The effect of temperature on the growth rate and survival of the immature stages of Aedes aegypti (L.). Bull. Entomol. Res. 49: 157-163.

Crovello, T. J. \& C. S. Hacker. 1972. Evolutionary strategies in life table characteristics among feral and urban strains of Aedes aegypti (L.). Evolution 26: 185-196.

Greever, J. \& G. P. Georghiou. 1979. Computer simulation of control strategies for Culex tarsalis (Diptera: Culicidae). J. Med. Entomol. 16: 180-188.

Haile, D. G. \& D. E. Weidhaas. 1977. Computer simulation of mosquito populations (Anopheles albimanus) for comparing the effectiveness of control strategies. J. Med. Entomol. 13: 553-567.

Kasule, F. K. 1986. A comparison of the life history components of Aedes aegypti (L.) and Culex quin- quefasciatus Say (Diptera: Culicidae). Insect Sci. Applic. 7: 143-147.

Laudien, H. 1973. Changing reaction systems, pp. 355-399. In H. Precht et al. [eds.], Temperature and life. Springer, New York.

Madder, D. J., G. A. Surgeoner \& B. V. Helson. 1983. Number of generations, egg production, and developmental time of Culex pipiens and Culex restuans (Diptera: Culicidae) in southern Ontario. J. Med. Entomol. 20: 275-287.

MeHugh, C. P. \& J. K. Olson. 1982. The effect of temperature on the development, growth and survival of Psorophora columbiae. Mosq. News 42: 608613.

Moon, T. E. 1976. A statistical model of the dynamics of a mosquito vector (Culex tarsalis) population. Biometrics 32: 355-368.

Rayah, E. A. E. \& N. A. A. Groun. 1983. Effect of temperature on hatching eggs and embryonic survival in the mosquito Culex quinquefasciatus. Entomol. Exp. Appl. 33: 349-351.

SAS Institute. 1982. SAS user's guide: statistics. SAS Institute, Cary, N.C.

Schoolfield, R. M., P. J. H. Sharpe \& C. E. Magnuson. 1981. Nonlinear regression of biological temperature-dependent rate models based on absolute reaction-rate theory. J. Theor. Biol. 88: 719-731.

Service, M. W. 1986. The biologies of Aedes caspius (Pallas) and Culex quinquefasciatus Say (Diptera: Culicidae) in Dubai. Insect Sci. Applic. 7: 11-18.

Sharpe, P. J. H. \& D. W. DeMichele. 1977. Reaction kinetics of poikilotherm development. J. Theor. Biol. 64: 649-670.

Shelton, R. M. 1973. The effect of temperatures on development of eight mosquito species. Mosq. News 33: 1-11.

Southwood, T. R. E., G. Murdie, M. Yasuno, R. J. Tonn \& P. M. Reader. 1972. Studies on the life budget of Aedes aegypti in Wat Samphaya, Bangkok, Thailand. Bull. W.H.O. 46: 211-226.

Stinner, R. E., G. D. Butler, Jr., J. S. Bacheler \& C. Tuttle. 1975. Simulation of temperature-dependent development in population dynamics models. Can. Entomol. 107: 1167-1174.

Wagner, T. L., H. I. Wu, P. J. H. Sharpe, R. M. Schoolfield \& R. N. Coulson. 1984. Modelling insect development rates: a literature review and application of a biophysical model. Ann. Entomol. Soc. Am. 77: 208-225.

Wagner, V. E., G. A. Tully, E. D. Goodman \& H. D. Newson. 1975. A computer simulation model for population studies of woodland pool Aedes mosquitoes. Environ. Entomol. 4: 905-919.

Walter, N. M. \& C. S. Hacker. 1974. Variation in life table characteristics among three geographic strains of Culex pipiens quinquefasciatus. J. Med. Entomol. 11: 541-550.

Received for publication 23 October 1989; accepted 20 March 1990. 